\title{
Analisis Sistem Reliability dengan Pendekatan Reliability Block Diagram
}

\section{Reliability System Analysis with Reliability Block Diagram Approach}

\author{
*Rifda Ilahy Rosihan dan Hari Agung Yuniarto \\ Program Studi Teknik Industri, Fakultas Teknik, Universitas Gadjah Mada
}

Submitted: 06-07-2018; Revised: 01-02-2019; Accepted: 09-02-2019

\begin{abstract}
A component / system can be declared reliable if in a certain period the system / component runs according to its function. Reliable indicators of a component can be seen from the value of reliability achieved by a system, decreasing downtime, increasing production time, and increasing availability values. In this paper, analysis of reliability carried out on the system of an automotive company is called PT. X which is a subsidiary from an automotive company. PT. X has the main process in the production process, namely the extrusion process. In the extrusion process there are fifteen machines arranged in series. To analyze system reliability in the Extrusion process, the Reliability Block Diagram method is used. Reliability Block Diagram is one of the reliability analysis methods that can describe the relationship between systems, sub-systems, and components so that components / systems can be identified that have an influence on the value of system reliability. The purpose of this study is to model the system using the Reliability Block Diagram method, find out the reliability of the entire system, and know critically equipment. The processed data is machine damage data from 2006-2017, then the data is processed to determine the reliability of each component. The software used is Reliasoft Blocksim 11. Software Reliasoft Blocksim Software is able to model, analyze, and simulate the RBD model. Reliasoft Blocksim software displays a flexible graphical image that supports various configurations of $R B D$, namely reliability, maintainability, availability, and resources allocation. The results of this study are the system reliability values of 0.00436 or $0.436 \%$ with $t=100$ hours.
\end{abstract}

Keywords: Availability; Reliability; Reliability Analysis; Reliability Block Diagram; Reliasoft Blocksim.

\begin{abstract}
ABSTRAK
Suatu komponen/sistem dapat dinyatakan handal apabila pada suatu periode tertentu sistem/komponen berjalan sesuai dengan fungsinya. Indikator handal suatu komponen dapat dilihat dari nilai reliability yang dicapai oleh suatu sistem, menurunnya downtime, meningkatnya waktu produksi, dan meningkatkan nilai availability Pada paper ini, analisis reliability dilakukan pada sistem dari suatu perusahan otomotif pada penelitian ini disebut sebagai PT.X yang merupakan anak perusahaan dari perusahaan otomotif. PT. $\mathrm{X}$ memiliki proses utama pada proses produksi yaitu proses extrusion. Pada proses extrusion terdapat lima belas mesin yang tersusun secara seri. Untuk menganalisis reliability sistem pada proses Extrusion digunakan metode Reliability Block Diagram. Reliability Block Diagram merupakan salah satu metode
\end{abstract}

*Corresponding author: h.a.yuniarto@ugm.ac.id

Copyright @ 2019 THE AUTHOR(S). This article is distributed under a Creative Commons Attribution-Share Alike 4.0 International license. Jurnal Teknosains is published by the Graduate School of Universitas Gadjah Mada. 
analisis reliability yang dapat mengambarkan hubungan antar sistem, sub-sistem, dan komponen sehingga dapat diketahui komponen/sistem yang memiliki pengaruh pada nilai reliability sistem. Tujuan dilakukannya penelitian ini adalah memodelkan sistem dengan menggunakan metode Reliability Block Diagram, mengetahui reliability dari keseluruhan sistem, dan mengetahui critically equipment. Data yang diolah merupakan data kerusakan mesin dari tahun 2006-2017, kemudian data tersebut diolah untuk menentukan reliability dari masing-masing komponen. Software yang digunakan adalah Software Reliasoft Blocksim 11. Software Reliasoft Blocksim mampu memodelkan, menganalisis, sampai mensimulasikan model RBD. Software Reliasoft Blocksim menampilkan gambaran grafis yang fleksibel yang mendukung beragam konfigurasi dari RBD, yakni reliability, maintainability, availability, dan resources allocation. Hasil dari penelitian ini adalah nilai reliability sistem 0,00436 atau $0,436 \%$ dengan $t=100$ jam.

Kata Kunci: Availability; Reliability; Reliability Analysis; Reliability Block Diagram; Reliasoft Blocksim.

\section{PENGANTAR}

Kinerja (performance) dari suatu mesin/ peralatan bergantung pada reliability dan availability, peralatan yang digunakan, proses operasi dan keahlian operator dalam menjalankan mesin, dan lain-lain. Apabila reliability dan availability rendah, maka performance dari sistem tersebut rendah. Untuk meningkatkan nilai reliability dan availability dilakukan penurunan laju kegagalan atau meningkatkan efektivitas perbaikan dari masing-masing komponen. Ukuran reliability dan availability dapat dinyatakan sebagai seberapa besar kemungkinan suatu sistem tidak akan mengalami kegagalan dalam waktu tertentu, seberapa lama suatu sistem akan beroperasi dalam waktu tertentu, dan berapa cepat waktu yang dibutuhkan untuk memulihkan kondisi sistem dari kegagalan yang terjadi (Yuhelson dkk., 2010). Reliability dan availability merupakan salah satu hal penting dalam kelangsungan hidup perusahaan. Adanya downtime seringkali menyebabkan kerugian, baik pada perusahaan maupun lingkungan sekitar. Downtime terjadi dikarenakan adanya failure pada peralatan sehingga sistem tidak berjalan dengan optimal (Soleimani dkk., 2014). Timbulnya downtime pada sistem disebabkan oleh failure pada komponen sehingga sistem tidak berjalan dengan semestinya. Oleh karena itu, diperlukan analisa reliability untuk meningkatkan performance sistem untuk mencegah timbulnya kegagalan yang tidak diprediksi, komponen yang tidak tersedia, dan shutdown secara tiba-tiba.

Penentuan komponen kritis pada sistem dapat dilakukan dengan menggunakan FMEA, seperti yang telah dilakukan oleh (Dewangan dkk., 2014) komponen yang memiliki nilai critical index lebih dari enam maka akan masuk kedalam komponen kritis. Selain dengan pendekatan FMEA, penentuan komponen kritis dapat pula dilakukan dengan pendekatan Reliability Block Diagram dengan penentuan Reliability Importance untuk mendapatkan komponen yang memiliki pengaruh dalam penentuan nilai reliability yang rendah.

Reliability Block Diagram (RBD) adalah teknik analisis grafis yang menunjukkan bagaimana keandalan komponen berkontribusi terhadap keberhasilan atau kegagalan sistem yang kompleks. RBD digambarkan pada sebuah rangkaian blok yang dihubungkan secara seri atau paralel. Masing-masing blok mewakili sistem atau komponen dengan tingkat kegagalannya masing-masing, rangkaian seri menyatakan logika "and" sehingga apabila satu komponen atau sistem gagal maka seluruh sistem akan gagal. Sebaliknya pada rangkaian paralel baru akan mengalami kegagalan apabila seluruh sistem atau komponen gagal(Mokhtar dkk., 2011). RBD menggambarkan keterkaitan antara sistem, sub-sistem, dan komponen. Gambaran sistem dengan menggunakan RBD memudahkan dalam menunjukkan komponen atau sub-sistem mana yang memiliki pengaruh besar pada nilai reliability sistem. RBD mampu melakukan perhitungan availability, unavailability, unreliability, failure frequency dan sekaligus menghitung MTTF, MTBF suatu sistem(Ludean dkk., 2018). Pada Reliability Block Diagram masing-masing subsistem, sistem, dan komponen memiliki model kegagalan yang independen, sehingga masing- 
masing komponen memiliki tingkat kerusakan yang berbeda untuk mencapai reliability system. Pada traditional RBD akan susah dalam memodelkan model yang kompleks, seperti standby, load sharing, branching, dan lain-lain sehingga perlu digabungkan dengan metode lain seperti Markov (Weyns dan Host, 2013). Terdapat beberapa kelebihan dari Reliability Block Diagram dalam memodelkan sistem (1) RBD mengambarkan hubungan logis antar sistem, sub-sistem dan komponen sehingga akan terlihat sistem, sub-sistem, komponen yang memiliki nilai reliability terendah. (2) RBD memodelkan sistem dari beberapa komponen ataupun sub-sistem yang memiliki tingkat kerusakan/tingkat perbaikan yang berbeda/ independen sehingga perhitungan reliability pada sistem berdasarkan pada tingkat kerusakan dan nilai reliability dari masing-masing komponen. (3) mudah digunakan, diadaptasikan dan mudah dalam perhitungan. Namun pada model RBD yang tradisional, RBD tidak mampu memodelkan model yang kompleks, seperti load sharing, standby, branching, dan lainlain, sehingga untuk memodelkan model yang kompleks RBD perlu digabungkan dengan metode lain.

Dalam memodelkan RBD terdapat berbagai macam metode, yaitu analythical dan simulation. Menurut (Kumar dkk., 2013) analythical method menggunakan formulasi mathematical yang kompleks, sehingga untuk model sistem yang besar dan komplek jarang digunakan. Salah satu tools atau pendekatan simulation pada pemodelan RBD adalah Reliasoft Blocksim. Software Reliasoft Blocksim mampu memodelkan, menganalisis, sampai mensimulasikan model RBD untuk model yang kompleks. Software Reliasoft Blocksim menampilkan gambaran grafis yang fleksibel yang mendukung beragam konfigurasi dari RBD, yakni reliability, maintainability, availability, dan resources allocation (Rajput dan Vaishali Chourey, 2015). Software Reliasoft Blocksim dapat menggambarkan blok - blok menjadi sebuah Reliability Block Diagram (RBD) untuk mewakili keseluruhan sistem dan menganalisis diagram untuk menentukan fungsi keandalan keseluruhan sistem. Selanjutnya Software
Reliasoft Blocksim dapat menentukan komponen kritis beserta indeks kekritisannya. Software Reliasoft Blocksim dapat digunakan untuk membuat perhitungan statistik dan membuat plot, untuk melakukan analisis "what-if" dan untuk menentukan optimalisasi keandalan sistem yang kita tentukan (Sunderam dan Mohan, 2011).

RBD merupakan salah satu metode yang digunakan untuk menentukan reliability sistem, seperti yang dilakukan (Rajput dan Chourey, 2015) memodelkan RBD untuk menentukan reliability sistem pada sistem online shopping. Pemodelan tersebut kemudian digunakan untuk meningkatkan nilai reliability sistem online shopping dengan mengubah model RBD. Demikian pula halnya dengan pabrik otomotif PT. X yang merupakan anak perusahaan dari perusahaan otomotif yang menyediakan spare part. Penelitian ini dilakukan di PT. X karena PT.X merupakan salah satu perusahaan otomotif besar yang menyediakan spare part pada perusahaan otomotif induk. PT. X diketahui memiliki tingkat kerusakan yang rendah seperti yang tertera pada Gambar 1 sehingga peneliti ingin mengetahui apakah tingkat reliability yang tinggi. Pada penelitian ini perusahaan disebutkan PT. X karena dari pihak perusahaan tidak ingin nama perusahaan ditampilkan. PT. X berusaha menjaga hubungan baik dengan perusahaan induk dan berusaha bersaing dengan supplier lain sehingga PT. $X$ berusaha meningkatkan performa perusahaan. PT. X merupakan salah satu anak perusahaan yang memiliki spesialisasi pada proses Extrusion. Proses Extrusion merupakan proses awal dan proses inti pada proses produksi sehingga apabila terjadi kegagalan pada proses Extrusion maka proses produksi selanjutnya akan terhenti. Kegagalan yang dimaksud pada penelitian ini adalah sistem tidak mampu bekerja sesuai dengan fungsinya, seperti mesin terhenti karena rusak atau karena perbaikan.

Pelaksanaan maintenance pada PT. X dengan cara preventive maintenance yang dilakukan sebulan sekali, dapat dilihat pada Gambar1, bahwa tingkat kerusakan pada proses Extrusion mengalami penurunan. Akan tetapi, 
pada kondisi nyata kerusakan pada proses Extrusion sering terjadi dan mengakibatkan line stop. Hal ini dapat mengakibatkan PT. X tidak mampu memenuhi kebutuhan konsumen, seperti keterlambatan dalam pengiriman spare part.

Gambar 1

Kerusakan Mesin pada Proses Extrusion di PT. X

Terjadinya pemberhentian proses (line

\section{Chart Kerusakan Proses Extrusion}

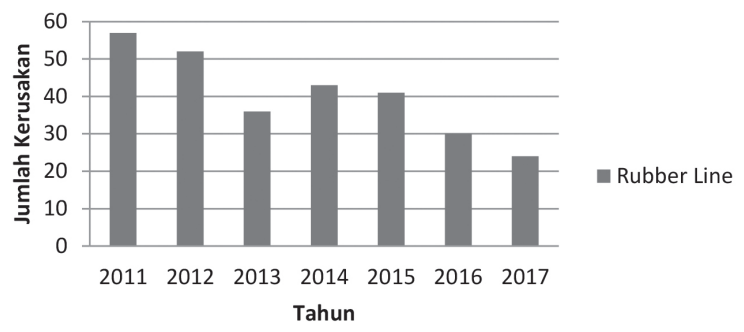

stop) berkaitan dengan nilai reliability sistem belum diketahui, sehingga kebijakan pergantian dan pemeriksaan mesin tidak terjadwal, inventory spare part yang belum terorganisir yang mengakibatkan proses pergantian spare part berlangsung lama. Meningkatkan nilai reliability dari suatu sistem dapat meningkatkan performance sistem dan meningkatkan nilai availability sistem. Jika reliability meningkat maka availability ikut meningkat, downtime menurun dan sistem akan berjalan dengan baik (Ebeling, 1997).

Oleh karena itu, dilakukan penelitian untuk menghitung nilai reliability pada sistem Extrusion guna mengurangi adanya kerusakan, meningkatkan reliability mesin, dan availability, membangun Reliability Block Diagram untuk proses Extrusion dengan menggunakan software Reliasoft Blocksim, dan mengetahui critical equipment pada sistem Extrusion.

\section{Reliability}

Reliability didefinisikan sebagai probabilitas komponen atau sistem akan beroperasi sesuai dengan fungsi yang diharapkan pada suatu periode waktu yang ditentukan dalam kondisi operasi tertentu. Untuk menentukan reliability, terlebih dahulu mendefinisikan reliability secara spesifik. Pertama, kegagalan (failure) terlebih dahulu didefinisikan arti kegagalan pada suatu sistem, sebagai contoh kegagalan pada sistem diartikan bahwa sistem tidak mampu beroperasi sesuai dengan fungsinya. Kedua, satuan waktu harus ditentukan, misal waktu interval kerusakan lebih spesifik, berdasarkan waktu kalendar, waktu siklus atau waktu interval. Pada beberapa kasus, reliability tidak diartikan pada satuan waktu namun pada ukuran lain seperti satuan mil, unit, atau batch. Ketiga, sistem diamati pada kinerja normal. Hal ini mencakup faktor-faktor seperti beban (berat, tegangan, tekanan), lingkungan, dan kondisi operasional (maintenance) (Ebeling, 1997).

Terdapat beberapa fungsi distribusi statistik yang digunakan untuk menguraikan kerusakan peralatan, yaitu:

Fungsi Distribusi Normal

Distribusi normal mempunyai laju kerusakan yang naik sejak bertambahnya umur alat, yang berati probabilitas kerusakan alat atau komponen naik sesuai dengan bertambahnya usia komponen. Parameter dalam distribusi normal adalah rata-rata dan standar deviasi

Fungsi Kepadatan peluang

$$
f(t)=\frac{1}{\sigma \sqrt{2 \pi}} e^{\left[\frac{-(t-\mu)^{2}}{2 \sigma^{2}}\right]}
$$

Fungsi Distribusi Kumulatif

$$
F(t)=\frac{1}{\sigma \sqrt{2 \pi}} \int_{-\infty}^{t} e^{\left[\frac{-(t-\mu)^{2}}{2 \sigma^{2}}\right]} d t
$$

(Taufik dan Septiani, 2015)

Fungsi Distribusi Eksponensial

Distribusi eksponensial mempunyai laju kerusakan yang konstan, tidak tergantung pada waktu artinya probabilitas terjadinya kerusakan pada suatu komponen tidak tergantung pada umur komponen tersebut. Parameter untuk eskponensial adalah $\beta$ Fungsi kemungkinan kumulatif

$$
F(t)=1-\mathrm{e}^{(-\lambda \mathrm{t})}
$$


Fungsi kepadatan peluang

$f(t)=\lambda e^{(-\lambda t)}$

Fungsi Keandalannya

$$
R(t)=\mathrm{e}^{(-\lambda \mathrm{t})}
$$

(Taufik dan Septiani, 2015)

Fungsi Distribusi Weibull

Distribusi weibull merupakan distribusi yang sering digunakan untuk menganalisis data kerusakan karena distribusi weibull dapat menjelaskan beberapa periode kerusakan. Parameter pada distribusi weibull:

$\beta=$ parameter bentuk

$\lambda=$ parameter lokasi

$\eta=$ parameter skala

Fungsi kepadatan peluang

$$
f(t)=\frac{\beta}{\alpha}\left(\frac{t}{\alpha}\right)^{\beta-1} e^{\left[-\left(\frac{t}{\alpha}\right)^{\beta}\right]}
$$

Fungsi distribusi kumulatif

$$
F(t)=1-e^{\left[-\left(\frac{t}{\alpha}\right)^{\beta}\right]} \ldots \mathrm{q}
$$

Fungsi keandalan

$$
R(t)=e^{\left[-\left(\frac{t}{\alpha}\right)^{\beta}\right]}
$$

(Taufik dan Septiani, 2015)

Reliability Block Diagram

Reliability Block Diagram (RBD) adalah analisis keandalan dan availability dari suatu sistem, baik untuk sistem besar dan kompleks yang digambarkan dalam diagram blok untuk menjelaskan hubungan antar sistem (ITEM Software, 2007). Reliability Block Diagram (RBD) merupakan salah satu metode Reliability Analysis yang mengambarkan hubungan antar sistem, sub-sistem, dan komponen.

\section{Rangkaian Seri}

Suatu sistem dapat dimodelkan dengan sususan seri jika komponen-komponen yang ada di dalam sistem itu harus bekerja dan berfungsi semuanya agar sistem tersebut dapat menjalankan fungsinya. Artinya jika ada satu komponen mengalami kegagalan maka keseluruhan sistem akan mengalami kegagalan.

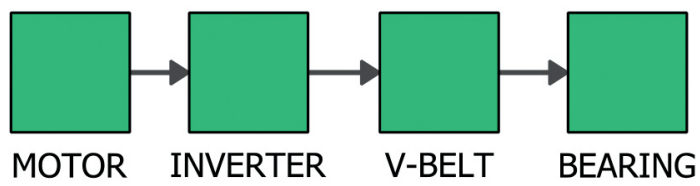

Gambar 2

Susunan Seri

$$
R_{S}=R_{1} R_{2} R_{3} \ldots \ldots R_{n}
$$

$\mathrm{R}_{\mathrm{s}}$ adalah reliability seri

$\mathrm{R}_{\mathrm{n}}$ adalah reliability pada urutan ke $\mathrm{n}$

(Ebeling, 1997)

Rangkaian Paralel

Suatu sistem dapat dimodelkan dengan susunan paralel jika seluruh komponen yang berada dalam sistem mengalami kerusakan. Artinya jika terdapat dua komponen yang disusun secara paralel akan mengalami kegagalan jika kedua komponen tersebut mengalami kegagalan.

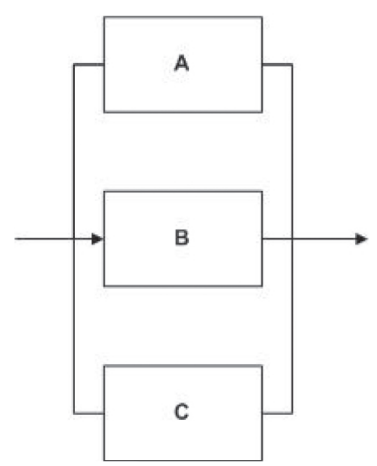

Gambar 3

Susunan Paralel

$$
R_{p}=1-\prod_{i=1}^{n}\left[1-R_{i}(t)\right]
$$

$\mathrm{R}_{\mathrm{p}}$ adalah reliability parallel (Ebeling, 1997) 


\section{Reliability Analysis}

Setelah menentukan keandalan sistem, hal berikutnya yang dilakukan adalah mengidentifikasi komponen yang paling banyak menimbulkan masalah pada sistem untuk memprioritaskan perbaikan dalam desain dan sumber daya dan upaya perbaikan sistem ke arah yang memiliki dampak paling besar terhadap kinerja sistem. Pada sistem sederhana seperti sistem seri, mudah untuk mengidentifikasi komponen yang lemah. Tetapi dalam sistem yang lebih kompleks dibutuhkan analisis dengan pendekatan matematis yang akan mengidentifikasi dan mengukur nilai dari masing - masing komponen. Reliability Importance merupakan salah satu metode untuk mengidentifikasi hubungan relasi dari masing - masing komponen dalam suatu sistem yang berkaitan dengan reliability dari keseluruhan sistem.

Reliability Importance dapat dirumuskan pada persamaan 11

$I_{R i}=\frac{\partial R_{S}}{\partial R_{i}}$

(Sianipar, 2008)

$\mathrm{R}_{\mathrm{s}}=$ keandalan sistem

$\mathrm{R}_{\mathrm{i}}=$ keandalan komponen

Time dependent reliability importance

$$
I_{r}(t)=\frac{\partial R_{S}(t)}{\partial R_{i}(t)}
$$

$\mathrm{R}_{\mathrm{s}} \quad(\mathrm{t})$ adalah keandalan sistem pada waktu tertentu, $\mathrm{t}$

$\mathrm{R}_{\mathrm{i}} \quad(\mathrm{t})$ adalah keandalan komponen pada waktu tertentu.

(Sianipar, 2008)

Bila dalam satu sistem terdapat tiga komponen dengan konfigurasi seri maka persamaannya menjadi:

$R_{S}=R_{1} R_{2} R_{3}$ maka $I_{R i}=\frac{\partial R_{S}}{\partial R_{i}}=R_{2} R_{3} \ldots$

(Sianipar, 2008)

Telah disebutkan sebelumnya bahwa setiap komponen dalam suatu keandalan sistem memiliki nilai keandalannya sendiri maka dalam melakukan perbaikan atau peningkatan keandalan sistem terlebih dahulu menentukan target keandalan sistem yang diharapkan (reliability goal) dan menentukan komponen mana yang akan dinaikkan keandalannya berdasarkan tingkat kekritisan, kesulitan dalam pelaksanaan, dan biaya yang paling optimum

Modifikasi keandalan komponen tidak semudah dengan membagi rata target keandalan sistem kepada masing - masing komponen secara merata, tetapi karena reliability importance, sifat dari komponen dan biaya menjadi pertimbangan dalam memodifikasi kehandalan komponen sehingga alokasi keandalan masing - masing komponen dapat berbeda (Sianipar, 2008).

\section{Reliasoft Blocksim}

Reliasoft Blocksim membantu dalam menggambarkan model dari Reliability Block Diagram (RBD) dan fault Tree Analysis (FTA), termasuk juga untuk memodelkan konfigurasi kompleks, load sharing, standby redundant, dan duty cycles. Dengan menggunakan perhitungan yang tepat dan/atau dengan discrete event simulation, Reliasoft BlockSim menyajikan analisis untuk sistem yang dapat diperbaiki dan tidak dapat diperbaiki, termasuk di dalamnya (Reliasoft, 2016)

\section{Metode}

Obyek penelitian ini adalah sistem Extrusion pada proses produksi di PT. X. PT. $X$ merupakan salah satu anak perusahaan dari perusahaan otomotif yang proses produksinya menghasilkan part - part karet untuk pintu dan jendela. Salah satu hasil produksi dari PT. X adalah windshield, inner, outer, dan lain-lain.

Pada proses produksi yang terjadi di PT. $X$ dibagi menjadi dua bagian, yakn proses produksi untuk bahan rubber dan berbahan plastik. Pada proses produks plastik dibagi lagi menjadi TPO dan PVC. Pada penelitian ini akan dibahas mengenai proses Extrusion pada proses produksi rubber line karena pada proses produksi rubber hanya terdapat satu proses (tidak ada penganti) atau tidak terdapat 
proses standby berbeda dengan line plastik yang memiliki proses standby sehingga apabila satu line plastik terhenti maka ada proses pada line plastik lain yang dapat menggantikan. Software yang digunakan adalah software Reliasoft Blocksim untuk memodelkan Reliability Block Diagram (RBD) dari sistem yang berjalan pada perusahaan. Gambaran dari penelitian ini ditunjukkan pada Gambar 4
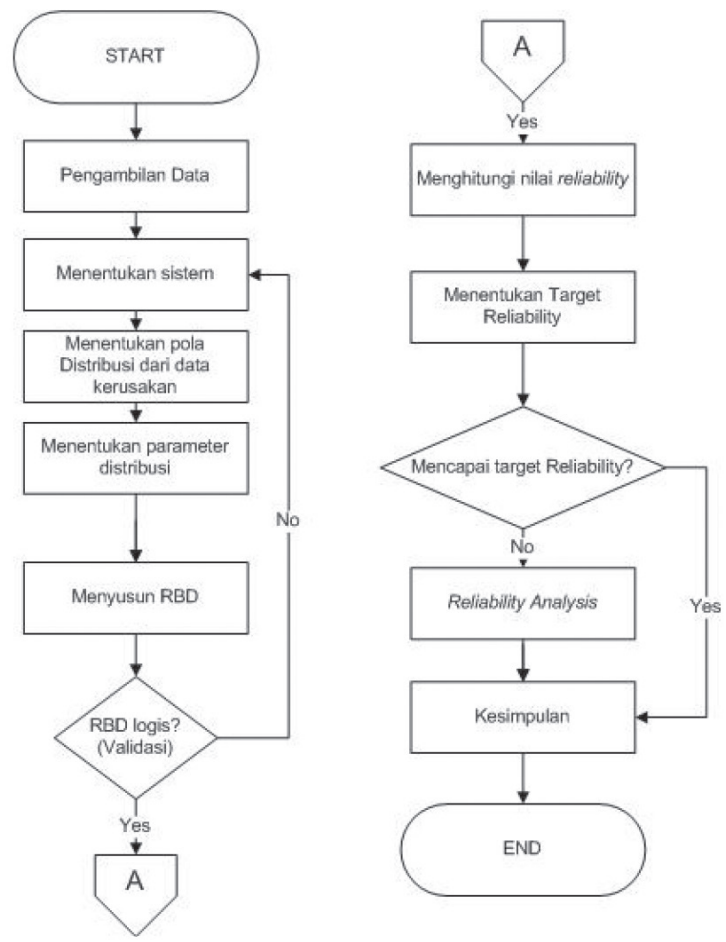

Gambar 4

Metode Penelitian

Pada Gambar 4 tahapan dari penelitian ini dimulai dari pengambilan data berupa data waktu antar kerusakan komponen, data lama waktu komponen diperbaiki, data waktu antar repair. Langkah berikutnya adalah menentukan sistem yang akan dihitung nilai reliability. Sistem ini merupakan scope penelitian, sebatas mana penelitian ini dan sampai pada level apa penelitian ini dilakukan. Pada penelitian ini, sistem yang akan diamati adalah sistem Extrusion pada PT.X. Kemudian menentukan pola distribusi dari waktu antar kerusakan. Pola distribusi waktu antar kerusakan mengikuti pola distribusi weibull, normal, eksponensial, atau yang lain. Setelah pola distribusi kemudian mengetahui parameter distribusi dari masingmasing komponen untuk menghitung nilai reliability sistem Extrusion. Tahap selanjutnya memodelkan RBD berdasarkan sistem, subsistem, dan komponen. Kemudian menghitung nilai reliability berdasarkan parameter distribusi masing-masing sistem, sub-sistem, komponen dan berdasarkan model RBD yang telah dibangun. Lalu menentukan target reliability sistem. Target reliability sistem berdasarkan pada kebijakan perusahaan. Pada penelitian ini perusahaan menentukan target reliability sistem sebesar 80\% (Munaji et al., 2016.). Selanjutnya melakukan reliability analysis untuk mengetahui komponen yang memiliki nilai reliability terendah. Terakhir menarik kesimpulan dari penelitian.

\section{HASIL DAN PEMBAHASAN Menentukan Sistem}

Sebelum memodelkan Reliability Block Diagram, terlebih dahulu dilakukan penentuan sistem, sub sistem, dan hubungan antara sistem dan sub-sistem. System tersebut kemudiann di breakdown kepada level sub-system sampai pada level komponen. Penentuan dan pengidentifikasi system ini didasarkan pada functional relationship pada system, sub-system dan komponen. Kemudian dilakukan penentuan hubungan antar subsystem, komponen yang ada dalam system. Hal ini dilakukan untuk mengetahui interaksi yang terjadi antar sub-system kemudian interaksi antar komponen, terlebih apabila komponen memiliki nilai reliability yang berbeda. Untuk mengetahui hubungan antar sistem dapat dilakukan dengan melihat Piping and Instrumention Diagram perusahaan

Pada penelitian ini sistem yang akan diteliti adalah sistem Extrusion pada proses produksi di PT. X. Proses Extrusion merupakan proses pembuatan bahan mentah menjadi profil setengah jadi. proses Extrusion melalui beberapa proses dalam satu line yakni proses welding (penyambungan), proses looping, proses pembentukan profil awal (extruder), proses 
pengembangan (microwave), proses pemanasan (oven), proses pendinginan (cooling), proses penarikan, proses peretakan (breaking), proses pembentukan profil (bending), dan terakhir proses cutting (pemotongan). Gambaran dari sistem Extrusion dapat dilihat pada Gambar 5.

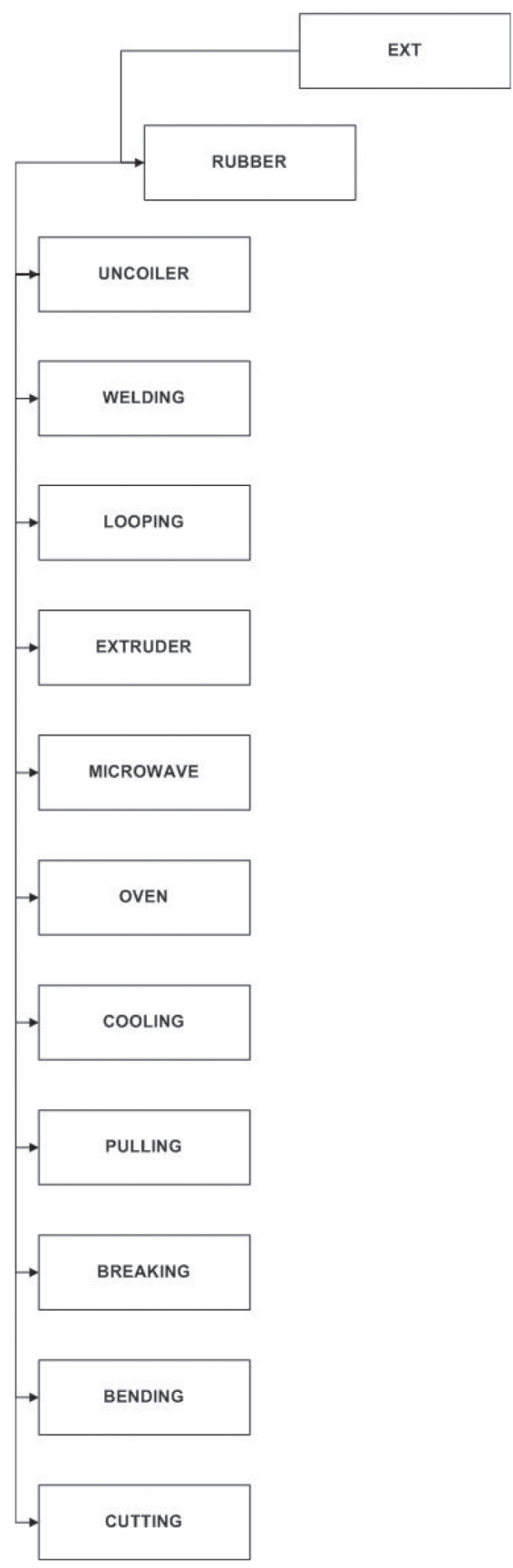

Gambar 5

Sistem pada Proses Extrusion

Gambar 5 merupakan gambaran proses Extrusion dimulai dari uncoiler, welding, looping, extruder, microwave (M_W), oven (HAV), cooling (cooling batch), pulling, breaking, bending, dan cutting.

\section{Reliability Block Diagram}

Reliability Block Diagram (RBD) adalah analisis keandalan dan availability dari suatu sistem, untuk sistem besar dan kompleks dengan menggunakan diagram blok untuk menunjukkan hubungan antar sistem. Reliability Block Diagram mendefinisikan interaksi logis kegagalan dalam sistem yang diperlukan untuk mempertahankan operasi sistem. Diagram hanya berisi satu input dan satu output. Sistem RBD dihubungkan oleh konfigurasi paralel atau seri. Pada proses Extrusion, keterkaitan antar mesin digambarkan dalam bentuk seri jadi, jika salah satu mesin mengalami kegagalan maka seluruh sistem akan berhenti. Reliability Block Diagram untuk proses Extrusion dapat dilihat pada Gambar 6

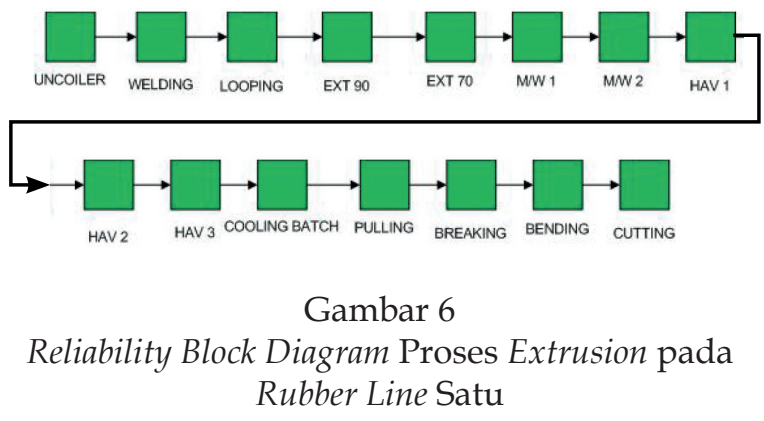

Gambar 6 merupakan model RBD dari proses Extrusion. Pada Gambar terlihat bahwa mesin pada proses Extrusion tersusun secara seri artinya bahwa jika salah satu mesin shutdown maka proses selanjutnya akan berhenti.

Penyusunan model RBD melibatkan pihak perusahaan dalam menerjemahkan diagram proses dan wiring diagram. Hal ini dikarenakan pada kondisi nyata, perusahaan belum memiliki variable yang dapat dibandingkan dengan hasil perhitungan dengan software yang menunjukkan bahwa model valid. Seperti nilai reliability, perusahaan belum melakukan perhitungan reliability pada masing-masing komponen sehingga hal ini tidak bisa dilakukan perbandingan hasil antara sistem nyata dengan hasil simulasi. Setelah memodelkan Reliability Block Diagram maka dapat dilakukan perhitungan reliability. Perhitungan reliability ini menggunakan software Reliasoft Blocksim. 
Sebelum menentukan nilai reliability terlebih dahulu menentukan distribusi dan parameter distribusi untuk masing-masing mesin.
Distribusi dan Parameter Distribusi dapat dilihat pada Tabel 1.

Tabel 1

Distribusi dan Parameter Distribusi untuk masing-masing Mesin

\begin{tabular}{llllll}
\hline \multicolumn{1}{c}{ Mesin } & \multicolumn{1}{c}{ Distribusi } & \multicolumn{1}{c}{ Beta } & \multicolumn{1}{c}{ Eta } & Mean Time & Gamma \\
Pulling & Weibull 2P & 0,698 & 3877,933 & & \\
Looping & Weibull 2P & 0,76 & 3321,329 & & \\
EXT 70 & Exponential 1P & & & 1723,609 & \\
EXT 90 & Weibull 2P & 0,809 & 1457,566 & & \\
HAV 1 & Weibull 2P & 1,248 & 2908,919 & & \\
HAV 2 & Weibull 2P & 1,085 & 2442,161 & & \multirow{2}{*}{ 155,059 } \\
HAV 3 & Exponential 2P & & & & \\
M/W 1 & Weibull 2P & 0,74 & 1856,761 & & \\
M/W 2 & Weibull 2P & 0,805 & 1364,895 & & \\
Cutting & Weibull 2P & 0,921 & 2151,06 & & \\
Breaking & Weibull 2P & 0,888 & 3299,231 & & \\
Bending & Exponential 2P & & & 2540,828 & \\
Cooling Batch & Weibull 2P & 0,526 & 4635,116 & & \\
\hline
\end{tabular}

Dari masing-masing distribusi yang dimiliki oleh masing-masing mesin, kemudian melakukan perhitungan nilai reliability pada masing-masing mesin. Nilai reliability ini merupakan ukuran probabilitas mesin berjalan sesuai dengan fungsinya. Hasil untuk nilai reliability dapat dilihat pada Tabel 2 .

Tabel 2

Nilai Reliability

\begin{tabular}{ll}
\hline \multicolumn{1}{c}{ Komponen } & \multicolumn{1}{c}{ Reliability (100) } \\
Looping & 0,878168 \\
EXT 70 & 0,538185 \\
EXT 90 & 0,538185 \\
Cooling Batch & 0,397727 \\
M_W 1 & 0,34149 \\
M_W 2 & 0,348758 \\
HAV 1 & 0,969786 \\
HAV 2 & 0,969786 \\
HAV 3 & 0,969786 \\
Pulling & 0,803166 \\
Breaking & 0,831898 \\
Bending & 0,787126 \\
Cutting & 0,755493 \\
\hline
\end{tabular}

Pada Tabel 2 di atas dapat diketahui bahwa terdapat tujuh komponen yang memiliki di bawah target reliability yang ditentukan oleh perusahaan yakni $85 \%$. Komponen tersebut adalah EXT 70, EXT 90, Cooling Batch, M_W 1, M_W2, Bending, Cutting.

\section{Reliability Analysis}

Untuk mencapai nilai reliability system yang ditargetkan maka sebelumnya diketahui terlebih dahulu mengenai mesin mana yang akan dinaikkan keandalannya berdasarkan tingkat kekritisan, kesulitan dalan pelaksanaan dan biaya yang paling optimum. Untuk menentukan hal tersebut perlu dilakukan reliability allocation untuk menemukan komponen yang perlu ditingkatkan nilai reliability-nya berdasarkan beberapa faktor, seperti faktor biaya, reliability importance, dan kesulitan dalam pelaksanaan. Reliability allocation pada sistem Extrusion, dihitung dengan menggunakan software Blocksim 11. Hasil untuk reliability allocation untuk sistem Extrusion dapat dilihat pada Tabel 3. 
Tabel 3

Reliability Allocation Sistem Extrusion pada masing - masing Mesin t=100 jam

\begin{tabular}{lllllll}
\hline \multicolumn{1}{c}{ Komponen } & $\begin{array}{c}\text { Max. Achievable } \\
\text { Reliability }\end{array}$ & Feasibility & RI (100) & $\begin{array}{c}\text { Reliability } \\
\mathbf{( 1 0 0 )}\end{array}$ & $\begin{array}{c}\text { Target } \\
\text { Reliability (100) }\end{array}$ & $\begin{array}{c}\text { Equivalent } \\
\text { Parallel Units * }\end{array}$ \\
Looping & 1 & Easy (1) & 0,004972 & 0,878168 & 0,993305 & 2,378189 \\
EXT 70 & 1 & Easy (1) & 0,008113 & 0,538185 & 0,981645 & 5,174583 \\
EXT 90 & 1 & Easy (1) & 0,008113 & 0,538185 & 0,981645 & 5,174583 \\
Cooling Batch & 1 & Easy (1) & 0,010978 & 0,397727 & 0,977428 & 7,476778 \\
M_W 1 & 1 & Easy (1) & 0,012786 & 0,34149 & 0,975794 & 8,907102 \\
M_W 2 & 1 & Easy (1) & 0,012519 & 0,348758 & 0,976004 & 8,696889 \\
HAV 1 & 1 & Easy (1) & 0,004502 & 0,969786 & 0,997524 & 1,714867 \\
HAV 2 & 1 & Easy (1) & 0,004502 & 0,969786 & 0,997524 & 1,714867 \\
HAV 3 & 1 & Easy (1) & 0,004502 & 0,969786 & 0,997524 & 1,714867 \\
Pulling & 1 & Easy (1) & 0,005436 & 0,803166 & 0,990431 & 2,860381 \\
Breaking & 1 & Easy (1) & 0,005249 & 0,831898 & 0,991498 & 2,673581 \\
Bending & 1 & Easy (1) & 0,005547 & 0,787126 & 0,98985 & 2,9671 \\
Cutting & 1 & Easy (1) & 0,005779 & 0,755493 & 0,988729 & 3,184585 \\
Reliability (100) & & & & 0,004366 & & \\
\hline
\end{tabular}

Tabel 3 menunjukkan reliability sistem Extrusion yaitu 0,00436 atau $0,436 \%$. Artinya bahwa dalam waktu $\mathrm{t}=100$ jam sistem beroperasi sesuai dengan fungsinya sebesar 0,436\%, selebihnya sistem berada kondisi shutdown atau gagal beroperasi. Untuk meningkatkan nilai reliability dibutuhkan waktu pengecekan dan perawatan yang lebih pendek sehingga mengurangi adanya kegagalan komponen dan membuat redundancy komponen. Nilai reliability sistem $0,436 \%$ dikarenakan tingkat kerusakan masing-masing komponen yang tinggi, dapat dilihat pada reliability untuk masing-masing komponen, seperti contoh komponen cooling batch memiliki nilai reliability 0,397727 artinya bahwa komponen ini memiliki probabilitas bekerja sesuai dengan fungsinya sebesar 39\%. Di samping itu, sistem ini dibangun secara seri sehingga jika terjadi kerusakan pada salah satu komponen maka komponen lain akan ikut terhenti. Selain itu, jika dilihat dari model matematis pada persamaan susunan seri (persamaan 9) reliability sistem merupakan hasil perkalian dari $R_{1}, R_{2}, R_{3^{\prime}} \ldots . R_{n}$ sehingga apabila terus dikalikan dengan semakin banyak nilai $R$ maka hasil dari Rsistem itu sendiri akan semakin kecil berbeda dengan persamaan susunan paralel (persamaan 10) di mana R sistem merupakan nilai dari $1-\left(\left(1-\mathrm{R}_{1}\right) \ldots\left(1-\mathrm{R}_{\mathrm{n}}\right)\right)$ artinya 1 dikurangi suatu nilai bilangan yang kecil maka akan menghasilkan $\mathrm{R}$ sistem yang besar. Oleh karena itu untuk meningkatkan reliability pada sistem Extrusion dapat dilakukan dengan penambahan komponen mesin yang dibentuk secara paralel atau standby sehingga apabila terjadi kerusakan pada salah satu mesin maka mesin satunya dapat menggantikan posisi mesin yang mengalami kerusakan dan sistem tidak shutdown.

\section{SIMPULAN}

Simpulanyang dapat ditarik dari penelitian ini adalah Reliability Block Diagram merupakan salah satu pendekatan yang dapat digunakan untuk melakukan perhitungan reliability sistem secara menyeluruh. Model RBD untuk sistem Extrusion dapat dilihat pada Gambar 6. Software yang digunakan untuk memodelkan RBD adalah software Reliasoft Blocksim. Reliability pada system Extrusion adalah 0,00436 atau $0,436 \%$ pada $t=100$ jam. Artinya bahwa dalam waktu $\mathrm{t}=100$ jam sistem beroperasi sesuai dengan fungsinya sebesar $0,436 \%$, selebihnya sistem berada kondisi shutdown atau gagal beroperasi. Untuk meningkatkan nilai reliability dibutuhkan waktu pengecekan dan perawatan 
yang lebih pendek sehingga mengurangi adanya kegagalan komponen dan membuat redundancy komponen. Critical equipment pada sistem Extrusion adalah Cooling Batch, M_W 1, dan M_W2.

Saran untuk penelitian selanjutnya diharapkan dapat menjabarkan komponen pada masing-masing sub-sistem pada sistem Extrusionon perlu dijelaskan lebih dalam dan penentuan maintenance strategy pada sistem dengan menggunakan metode Reliability Centered Maintenance dan Root Cause Analysis.

\section{DAFTAR PUSTAKA}

Dewangan, D.N., Jha, M.J., Y.P. Banjare, 2014. Reliability Investigation of Steam Turbine Used In Thermal Power Plant. International Journal of Innovative Research in Science, Engineering and Technology, 3: 14915-14923.

Ebeling, C.E., 1997. An Introduction to Reliability and Maintainability Engineering. McGraw-Hill: USA.

ITEM Software, 2007. Reliability Block Diagram. ITEM Software Inc.

Kumar, G., Jain, V., Gandhi, O.P., 2013. Availability Analysis of Repairable MechanicalSystems Using Analytical Semi-Markov Approach. Quality Engineering, 25: 97-107. https:// doi. org/10.1080/08982112.2012.751606

Ludean, D., Cretu, A., Munteano, R., Moga, R., Stroia, N., Moga, D., Vladareanu, L., 2018. Reliability Approach of a Compressor System using Reliability Block Diagrams. Journal of Fundamental and Applied Science, 10: 149-154. http://dx.doi. org/10.4314/jfas.v10i4s.74

Mokhtar, A.A., Muhammad, M., Hussin, H., Majid, M.A.A., 2011. Development of a RAM Simulation Model for Acid Gas Removal System. International Journal of Mechanical and Mechatronics Engineering, 5: 2587-2590.

Munaji, A., Ilhami, M.A., Kurniawan, B., 2016. Usulan Penjadwalan Perawatan
Mesin Dengan Mempertimbangkan Reliability Block Diagram Pada Unit Stand CPL Di PT Krakatau Steel. Jurnal Untirta, 4

Rajput, B.S., Vaishali Chourey, 2015. UML based Approach for System Reliability Assessment. International Journal of Computer Applications, 131: 17-24.

Reliasoft, 2016. Quick Start Guide Blocksim Version 10. Reliasoft Corporation, USA.

Sianipar, H., 2008. Evaluasi Program Pemeliharaan Pabrik Amoniak Usulan dan Pemecahannya dalam Usaha Mengurangi Shutdown Pabrik dan Memperpanjang Turn Around Interval (Studi Kasus di Unit Front End pabrik Amoniak PT. Pupuk Kaltim).Tesis. Universitas Gadjah Mada, Program Studi Teknik Mesin.

Soleimani, M., Pourgol-Mohammad, M., Ali Rostami, Ahmad Ghanbari, 2014. Design for Reliability of Complex System: Case Study of Horizontal Drilling Equipment with Limited Failure Data. Journal of Quality and Reliability Engineering, 2014: 3-11.

Sunderam, G., Mohan, R., 2011. Integrated System-Reliability Analysis for Wind Turbine. International Journal of Production Technology and Management Research. 2: 9-16.

Taufik, Septiani, S., 2015. Penentuan Interval Waktu Perawatan Komponen Kritis Pada Mesin Turbin Di Pt Pln (Persero) Sektor Pembangkit Ombilin. Jurnal Optimasi Sistem Industri, 14: 238-258.

Weyns, K., Host, M., 2013. Case Study on Risk Analysis for Critical Systems with Reliability Block Diagrams, The 10th International ISCRAM Conference, ISCRAM, Germany.

Yuhelson, Syam, B., Sinullingga, S., Isranuri, I., 2010. Analisis Reliability dan Availability Mesin Pabrik Kelapa Sawit PT. Perkebunan Nusantara 3. Jurnal Dinamis, 2: 6-22. 